\title{
LYMPHANGIOMA OF THE SMALL INTESTINE CASE REPORT AND REVIEW OF THE LITERATURE
}

Igor Ignjatovic ${ }^{1}$, Vladimir Milosavljevic ${ }^{2}$, Boris Tadic ${ }^{1}$, Nikola Grubor ${ }^{1}$ and Slavko Matic ${ }^{1}$ ${ }^{1}$ Clinic for Digestive Surgery of the CCS - First Surgical Clinic, Belgrade, Serbia ${ }^{2}$ General Hospital Stefan Visoki, Smederevska Palanka, Serbia

\author{
LIMFANGIOM TANKOG CREVA - \\ PRIKAZ SLUČAJA I PREGLED LITERATURE \\ Igor Ignjatović ${ }^{1}$, Vladimir Milosavljević ${ }^{2}$, Boris Tadić $^{1}$, Nikola Grubor ${ }^{1}$ i Slavko Matić ${ }^{1}$ \\ ${ }^{1}$ Klinika za digestivnu hirurgiju Klinčkog Centra Srbije - Prva hirurška klinika, Beograd, Srbija \\ ${ }^{2}$ Opšta Bolnica Stefan Visoki, Smederevska Palanka, Srbija
}

\begin{abstract}
Lymphangioma usually occurs in children and usually involves the skin. Mesenteric lymphangiomas are extremely rare in adults $(1,2,3)$. Lymphangioma of the small-bowel mesentery is rare, representing less than $1 \%$ of all lymphangiomas (4).

We report a case of a 62-year-old female who presented with abdominal pain, discomfort, nausea and vomiting. Preoperative tests including abdominal ultrasonography and magnetic resonance imaging were performed, but they could not accurately determine the nature of the tumour. Laparotomy was performed; the tumour was excised completely, and a large cystic tumour of the small bowel mesentery was found. Histopathological examination diagnosed the tumour as a cystic lymphangioma. Lymphangiomas are extremely rare, especially in the abdomen of adults, and are asymptomatic for the most part; they often present as acute abdominal conditions, causing life-threatening complications such as secondary infection, rupture with haemorrhage, and volvulus or intestinal obstruction when the tumour increases in size, requiring emergent surgery. Lymphangioma is often difficult to diagnose, and surgical resection is selected in many cases for both diagnosis and treatment.
\end{abstract}

Keywords: lymphangioma, small intestine, cystic, surgical excision

\section{SAŽETAK}

Limfangiom se obično javlja kod dece, najčešće na koži. Mezenterični limfangiomi su izuzetno retki kod odraslih. Mezenterični limfangiom tankog creva je retka pojava i obuhvata manje od 1\% svih limfangioma.

Predstavljamo slučaj žene stare 62 godine koja je imala tegobe u vidu bola u trbuhu, nelagodnosti, mučnine $i$ povraćanja. Preoperativna ispitivanja, koja su radena uključujući ultrasonografski pregled abdomena $i$ magnetnu rezonancu, nisu mogla tačno odrediti prirodu tumora. Učinjena je laparotomija i tumor je izvaden u celosti. Otkriven je veliki cistični tumor mezenterijuma tankog creva. Histopatološkim pregledom dijagnostikovan je tumor kao cistični limfangiom. Iako su limfangiomi izuzetno retki, posebno u abdomenu odraslih osoba $i$ asimptomatski u većini slučajeva, oni često prezentuju kao akutni abdomen, uzrokujući komplikacije opasne po život, kao što su sekundarna infekcija, ruptura sa hemoragijom, volvulus ili opstrukcija creva kada se tumor uveća i koje zahtevaju hitno operativno lečenje. Limfangiom je često teško dijagnostikovati, u mnogim slučajevima je izabrana hirurška resekcija u clju dijagnostike i lečenja.

Ključne reči: limfangiom, tanko crevo, cistični, hirurška ekscizija 


\section{INTRODUCTION}

Lymphangiomas most often occur in the head, neck, axilla, or groin of young children. Occasionally, the tumour is also discovered in adults in various other anatomical sites (3). Approximately $95 \%$ of lymphangiomas are found in the neck and axilla and the other 5\% occur in the mediastinum and abdominal cavity, including the mesentery, retroperitoneum and bones (5). Intra-abdominal lymphangiomas (fewer than $5 \%$ ) have been reported in the mesentery, gastrointestinal tract, spleen, liver and pancreas (6). Lymphangiomas are traditionally classified into three histologic types: capillary (simple), cavernous, and cystic (7). The capillary type usually originates in the skin and consists of uniform, small, thin-walled lymphatic spaces. The cavernous type is composed of various sizes of dilated lymphatic spaces associated with the lymphoid stroma and shows a connection with the adjacent normal lymphatic spaces. The cystic type consists of dilated lymphatic spaces of various sizes associated with collagen and smoothmuscle bundles in the stroma but lacks connection to the adjacent normal lymphatic spaces. Cystic lymphangioma findings are similar to cavernous lymphangioma findings in that dilated lymphatic spaces of variable size are seen for both (8). The aetiology of lymphangiomas is still unclear. They are considered to be a congenital dysplasia of lymphatic tissue and abnormal development of the lymphatic vessels during foetal life $(9,10)$. The histological features of lymphangioma were first described by Gaudier and Gorse in 1913 (11). The clinical symptoms of gastrointestinal and mesenteric lymphangiomas vary from asymptomatic to acute abdominal symptoms such as obstruction or bleeding, according to the size and the localization of the tumour $(10,12,13)$. The treatment is mainly surgical and consists of enucleation when feasible. Segmental intestinal resection is achieved when the cyst adheres intimately to the bowel $(13,14)$. The clinical features of intra-abdominal lymphangiomas are diverse, ranging from an asymptomatic abdominal tumour to symptoms of an acute abdomen (15). Therefore, a mass may be discovered incidentally during examination for an unrelated illness.

\section{CASE REPORT}

A 62-year-old female was admitted to our hospital for close examination and treatment due to unexplained intermittent abdominal pain especially in the left abdominal area, abdominal discomfort, nausea and vomiting. She had no history of abdominal surgery. The symptoms occurred over the past 6 months.

The physical findings were non-specific. The laboratory findings were within the reference ranges, and the tumour markers (AFP, CEA, CA 19-9, CA 15-3, CA125, TPS) were negative. Magnetic resonance imaging (MRI) of the abdomen and pelvis was performed (figure 1a,b). The patient did not present any other multicentric lymphatic

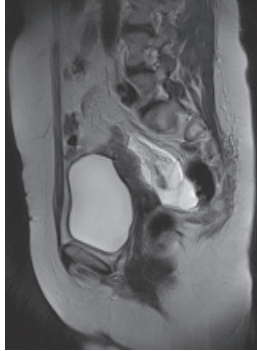

$1 \mathbf{a}$

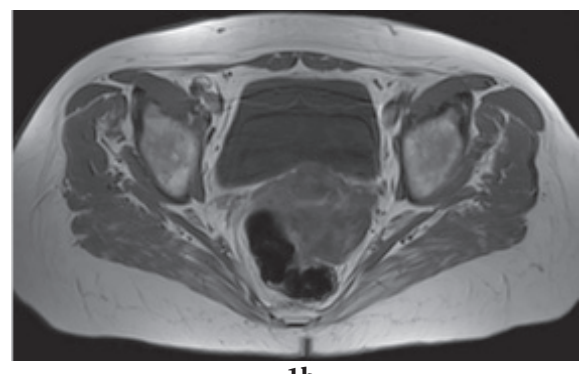

1b
Figure 1a: Sagittal T2-weighted MR image shows a high signal intensity multilocular lesion in the recto-uterine pouch.

Figure 1b: Axial T1-weighted image shows low signal intensity within the lymphangioma.

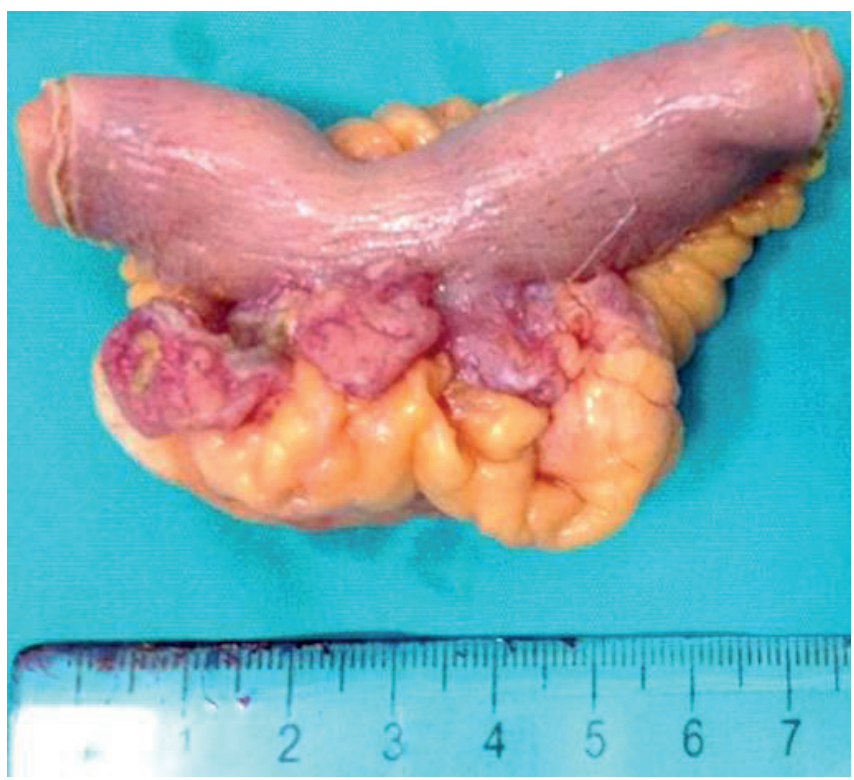

Figure 2: Resected segment of the small bowel with the infiltrating tumour mass

or vascular malformation. Her family and medical history were unremarkable.

Laparotomy was performed, and the tumour was excised completely with small-bowel resection and end-toend anastomosis. During the laparotomy, a yellowish cystic tumour with a soft consistency was found in the mesentery of the ileum (figure 2). The mesenteric mass was lobulated, cystic and measured approximately $20 \mathrm{~mm} \times 15 \mathrm{~mm} \times 13$ $\mathrm{mm}$. The mass consisted of multiple well-defined locules measuring between $4 \mathrm{~mm}-10 \mathrm{~mm}$, some were filled with a milky fluid with a volume of approximately $100 \mathrm{~mL}$. There was no communication between the cystic mass and the lumen of the small bowel. The tumour was not adherent to the wall of the intestine or adjacent organs. No ascites was seen in the peritoneal cavity, nor was there any dilatation or inflammatory change of the intestines or mesentery.

Microscopic examination revealed that the cystic walls comprised of smooth muscle were lined with flat endothelial cells (figure 3). The cystic walls were generally thin. The stroma showed various sizes of small lymphatic spaces lined by a flat endothelium. Few subendothelial lymphoid 


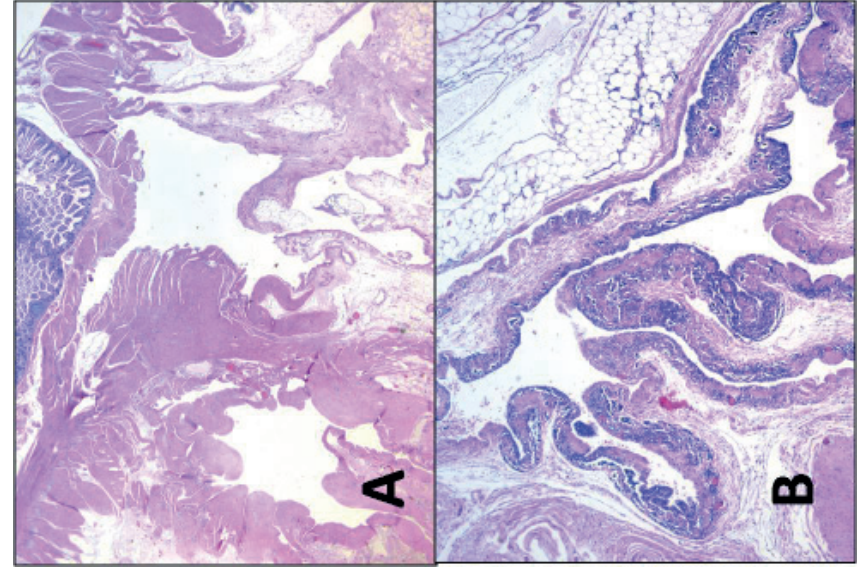

Figure 3. The intestinal wall revealed lymphatic malformation and presented irregular vascular channels with propagation into the mesenteric fat $(A, H \& E, 20 x)$ containing a scattered collection of smooth muscle in the walls of the larger vascular channels accompanied by a dense perivascular lymphoid infiltration (B, H\&E, 50x).

follicles were observed, supporting the diagnosis of cystic lymphangioma.

The procedure was tolerated well by the patient, without any clinically significant postoperative complications. The postoperative period was uneventful, and the patient was discharged on the fifth postoperative day.

Regular check-ups demonstrated that the patient was completely symptom and disease free. One year after surgery, an abdominal CT revealed no signs of disease recurrence.

\section{DISCUSSION}

As many as $90 \%$ of lymphangiomas present in children younger than 3 years, and the sex ratio is roughly equal in childhood (7). These tumour masses are extremely rare in adults. These cases account for less than 1 in 20,000 to 1 in 250,000 hospital admissions $(16,17)$, and they are more frequently observed in men than women with a $\mathrm{M} / \mathrm{F}$ ratio of 3:1 (18)

This condition is probably a developmental anomaly of the lymphatic system, explained by its primary occurrence in children, with over $80 \%$ diagnosed in the first few years of life (19). This theory would explain why lymphangiomas occur primarily in children. However, it is suggested that abdominal trauma, lymphatic obstruction, inflammatory processes, surgery, or radiation therapy may lead to the secondary formation of such a tumour $(16,17)$.

A review of the English language literature for the 50year period from 1960 to 2009 revealed only 19 reports of small bowel lymphangiomas $(20,21)$. A total of 40 patients are reported, with a wide age range at presentation from 5 to 75 years, and an equal gender distribution has been observed. Of the cases in which a specific anatomical small bowel location was noted, 24 were within the jejunum and 5 in the ileum (20). Hanagiri and colleagues also documented an additional 33 patients from the Japanese litera- ture between 1967 and 1990. In addition to the 19 English literature reports, 8 were from the Far East, including 5 Japanese and 3 Taiwanese manuscripts, suggesting that there may be a Japanese/Taiwanese predisposition to small bowel lymphangiomas. In the Japanese language literature, although the age distribution was comparable, there were twice as many males as females with an equal distribution between ileum and jejunum (20).

Lymphangiomas are traditionally classified into three histologic types: capillary (simple), cavernous, and cystic (7). The capillary type usually originates in the skin and consists of uniform small thin-walled lymphatic spaces. The cavernous type is composed of various sizes of dilated lymphatic spaces associated with lymphoid stroma and shows a connection with the adjacent normal lymphatic spaces. The cystic type consists of dilated lymphatic spaces of various sizes associated with collagen and smoothmuscle bundles in the stroma but lacks connection to the adjacent normal lymphatic spaces. Cystic lymphangioma findings are similar to cavernous lymphangioma findings in that dilated lymphatic spaces of variable size are seen in both (19).

Patients with mesenteric lymphangiomas are usually asymptomatic and the mass is discovered only incidentally during examination or surgery for an unrelated illness until the tumours enlarge. Abdominal pain, the presence of a palpable mass and distention seem to be the most common symptoms, but the clinical presentation varies.

The mass is usually discovered only incidentally during examination or surgery for an unrelated illness; however, some patients may have acute clinical symptoms caused by compression of the adjacent structures or by complications such as infection, perforation, torsion and rupture (22). However, mesenteric lymphangiomas may cause complications such as infiltration of the intestine, or involvement of the main branch of the mesenteric arteries or adjacent organs that necessitate segmental resection of the intestine $(23,24,25)$

The reason for reporting this case is to emphasize the fact that the primary treatment for lymphangiomas is radical surgical excision, even when asymptomatic, because of its potential to grow remarkably and invade adjacent structures or develop complications; they also have a risk of sarcoma transformation upon irradiation.

Other submucosal tumours, such as leiomyoma, lipoma or other cystic lesions, such as enteric duplication cysts as well as carcinoid tumours or mucocele, should be considered as the differential diagnoses. Preoperative investigations, including $\mathrm{CT}$ and MRI, give information about anatomical position, size and extent of the cysts, but they are insufficient in establishing an accurate preoperative diagnosis (26). Sometimes radical resection might be technically impossible. If radical surgery is not technically possible, injection of bleomycin or OK-432 into the tumour has been reported to be effective (27).

Mesenteric lymphangiomas are very rare, but they can cause acute abdominal symptoms that require emergent 
surgery. Therefore, they should be included in the differential diagnosis of the acute abdominal condition. Although benign in nature, mesenteric lymphangiomas may cause significant morbidity or mortality due to their large size and critical location when they compress the adjacent structures.

\section{REFERENCES}

1. Vargas-Serrano, B., N. Alegre-Bernal, B. CortinaMoreno, R. Rodriguez-Romero and F. Sanchez-Ortega (1995). "Abdominal cystic lymphangiomas: US and CT findings.” Eur J Radiol19(3): 183-187.

2. Chung, J. H., Y. L. Suh, I. A. Park, J. J. Jang, J. G. Chi, Y. I. Kim and W. H. Kim (1999). "A pathologic study of abdominal lymphangiomas." J Korean Med Sci14(3): 257-262.

3. Yoshida, Y., T. Okamura, T. Ezaki, K. Yano, M. Kodate, I. Murata and M. Kaido (1994). "Lymphangioma of the oesophagus: a case report and review of the literature." Thorax49(12): 1267-1268.

4. Jang, J. H., S. L. Lee, Y. M. Ku, C. H. An and E. D. Chang (2009). "Small bowel volvulus induced by mesenteric lymphangioma in an adult: a case report." Korean J Radiol10(3): 319-322.

5. Huang, J. C., J. S. Shin, Y. T. Huang, C. J. Chao, S. C. Ho, M. J. Wu, T. J. Huang, F. J. Chang, K. S. Ying and L. P. Chang (2005). "Small bowel volvulus among adults." J Gastroenterol Hepatol20(12): 1906-1912.

6. Koenig, T. R., E. M. Loyer, G. J. Whitman, A. K. Raymond and C. Charnsangavej (2001). "Cystic lymphangioma of the pancreas.” AJR Am J Roentgenol177(5): 1090.

7. Chen, C. W., S. D. Hsu, C. H. Lin, M. F. Cheng and J. C. $\mathrm{Yu}$ (2005). "Cystic lymphangioma of the jejunal mesentery in an adult: a case report." World J Gastroenterol11(32): 5084-5086.

8. Seki, H., T. Ueda, T. Kasuya, H. Kotanagi and T. Tamura (1998). "Lymphangioma of the jejunum and mesentery presenting with acute abdomen in an adult." J Gastroenterol33(1): 107-111.

9. Paal, E., L. D. Thompson and C. S. Heffess (1998). "A clinicopathologic and immunohistochemical study of ten pancreatic lymphangiomas and a review of the literature." Cancer82(11): 2150-2158.

10. Abe, H., K. Kubota, T. Noie, Y. Bandai and M. Makuuchi (1997). "Cystic lymphangioma of the pancreas: a case report with special reference to embryological development." Am J Gastroenterol92(9): 1566-1567.

11. Gaudier H, Gorse P. Lymphangiome kystique abdoménoscrotal retropéritonéal. Presse Méd 1913;21:458-89

12. Huang, Q., M. A. Minor and H. C. Weber (2009). "Clinical challenges and images in GI. Diagnosis: Cav- ernous lymphangioma of the jejunum." Gastroenterology136(4): 1170, 1465.

13. Mabrut JY, Grandjean JP, Henry L, Chappuis JP, Partensky C, Barth X, Tissot E. (2002).Mesenteric and mesocolic cystic lymphangiomas- Diagnostic and therapeutic management. Ann Chir.127(5):343-9.

14. Hardin WJ, Hardy JD. (1970) Mesenteric cysts. Am J Surg.119:640-645.

15. Daniel, S., B. Lazarevic and A. Attia (1983). "Lymphangioma of the mesentery of the jejunum: report of a case and a brief review of the literature." Am J Gastroenterol78(11): 726-729.

16. Losanoff, J. E., B. W. Richman, A. El-Sherif, K. D. Rider and J. W. Jones (2003). "Mesenteric cystic lymphangioma." J Am Coll Surg196(4): 598-603.

17. Wani, I. (2009). "Mesenteric lymphangioma in adult: a case series with a review of the literature." Dig Dis Sci54(12): 2758-2762.

18. Kurtz, R. J., T. M. Heimann, J. Holt and A. R. Beck (1986). "Mesenteric and retroperitoneal cysts." Ann Surg203(1): 109-112.

19. Hanagiri, T., M. Baba, T. Shimabukuro, M. Hashimoto, H. Takemoto, A. Inoue, A. Sugitani and T. Shirakusa (1992). "Lymphangioma in the small intestine: report of a case and review of the Japanese literature." Surg Today22(4): 363-367.

20. Shyung LR, Lin SC, Shih SC, et al. (2009) Proposed scoring system to determine small bowel mass lesions using capsule endoscopy. J Formos Med Assoc ;108:533-8.

21. De Vries, J. J., J. M. Vogten, P. C. de Bruin, D. Boerma, H. D. van de Pavoordt and J. Hagendoorn (2007). "Mesenterical lymphangiomatosis causing volvulus and intestinal obstruction." Lymphat Res Biol5(4): 269-273.

22. Steyaert H, Guitard J, Moscovici J, Juricic M, Vaysse P, Juskiewenski S.(1996) Abdominal cystic lymphangioma in children: benign lesions that can have a proliferative course. J Pediatr Surg. 31(5):677-80.

23. Griffa, B., V. Basilico, M. Feltri and A. Griffa (2006). "[Submucosal jejunal lymphangioma: an unusual case with obscure gastrointestinal bleeding in an adult, detected by video-capsule endoscopy and treated by laparoscopy]." Minerva Chir61(6): 529-532.

24. Rieker, R. J., A. Quentmeier, C. Weiss, U. Kretzschmar, K. Amann, G. Mechtersheimer, H. Blaker and O. F. Herwart (2000). "Cystic lymphangioma of the small-bowel mesentery: case report and a review of the literature." Pathol Oncol Res6(2): 146-148.

25. Siddique, K., S. Bhandari and S. Basu (2010). "Giant mesenteric lymphangioma: a rare cause of a life-threatening complication in an adult." BMJ Case Rep2010.

26. Tsukada, H., K. Takaori, S. Ishiguro, T. Tsuda, S. Ota and T. Yamamoto (2002). "Giant cystic lymphangioma of the small bowel mesentery: report of a case." Surg Today32(8): 734-737 